\title{
Islamforskning og islamiske studier på Københavns Universitet
}

Samlet set har det seneste tiår for islamforskningen og for islamiske studier på Københavns Universitet været produktive, men omskiftelige og brogede. Siden Muhammedkrisens klimaks i begyndelsen af 2006 til nu har islamforskningen på Københavns Universitet set en betydelig opnormering af forskningsindsatsen. Det har været i form af den store islamsatsning, som Københavns Universitet var vært for fra 2008 til 2013, men også nye stærke centre og bevillinger gør, at islamforskningen fortsat er i fokus. Sammen med forskningen følger en internationalt rost, men hårdt dimensioneret kandidatuddannelse $\mathrm{i}$ islamiske studier, der markerer nye udfordringer for faget - ligesom mange andre af universitetets fag, der har været igennem lignende dimensioneringer, oplever det.

Historisk set var studiet af islam på Københavns Universitet gennem meget lang tid et område, der på forskellig vis blev varetaget af personer, der enten var ansat som professorer i semitisk og østerlandsk filologi eller var ansat, som eksempelvis Johannes Østrup, i et særligt ekstraordinært professorat. Frants Buhl bidrog i 1903 med en banebrydende metodisk afhandling, $M u$ hammeds Liv. Med en Indledning om Forholdene i Arabien før Muhammeds Optrceden, der i 1930 udkom i tysk oversættelse.

Niels Valdemar Vinding, ph.d., er adjunkt ved Institut for Tværkulturelle og Regionale Studier på Københavns Universitet, hvor han forsker og underviser $\mathrm{i}$ islam og muslimer i Danmark og Europa med særlig fokus på sharia, religion og ret, religion og politik. Med støtte fra Carlsberg fondet handler hans aktuelle forskning om "Imamer i Vesten." Det er en kvalitativ, religionssociologisk interviewundersøgelse af mellem 50 og 60 imamer i Europa og Nordamerika, som afsluttes sommeren 2017. 
Johannes Østrup, der i 1918 blev ekstraordinær professor i islam, udgav i 1911 Profeten Muhammad. En folkelig Fremstilling og i 1914 Islam. Den muhammedanske Religion og dens historiske Udvikling i kortfattet Fremstilling. Buhl udgav i 1921 Ali som Proetendent og Kalif og i 1924 Muhammeds religiøse Forkyndelse efter Quranen. Hans efterfølger Johannes Pedersen udgav i 1923 efter studier i Cairo Muhammedansk Mystik. En Samling Texter oversat og forklaret af Johs. Pedersen, der i 1960 blev fulgt op med Kitab Tabaqat al-Sufyya. Texte arabe avec une introduction et un index par Johannes Pedersen, ligesom han skrev flere grundige bidrag om islam til større religionshistoriske værker. Frede Løkkegaard efterfulgte i 1950 Pedersen og udgav samme år Islamic Taxation in the Classical Period og i 1972 Muhammad. Jørgen Bæk Simonsen disputerede i 1988 med afhandlingen Studies in the Genesis and Early Development of the Caliphal Taxation System, og Jakob Skovgaard-Petersen i 1997 med Defining Islam for the Egyptian State: Muftis and Fatwas of the Dâr al-Iftâ.

Længe var islamforskningen på den måde et fagfelt indlejret i arbejdet med Mellemøsten og arabisk sprog, men også et fagfelt med stærke relationer til religionsfaget, der har leveret substantielle bidrag til islamforskningen og samfundsdebatten om islam. I 2004, efter sammenlægningerne af mange forskellige afdelinger på humaniora til det institut, der nu hedder TORS Tværkulturelle og Regionale Studier, er det blevet tydeligt, at islamforskning er bredere forankret både tvær-regionalt og tværdisciplinært. Med baggrunde fra mellemøststudier, religionsstudier, arkæologi, historie, antropologi og sprogvidenskab i bredeste forstand er det problemstillingerne, emnerne og nysgerrigheden, der står i forgrunden, og det, som giver et islamfagligt fællesskab på tværs af instituttet. Ligeledes er især samspillet med Det Teologiske Fakultet og Det Juridiske Fakultet frugtbart og giver noget nær kritisk masse for kvalificeret islamforskning i international klasse på Københavns Universitet.

Dette essay er skrevet på opfordring fra TIFOs redaktion for at give et indblik i islamforskningen og islamiske studier på Københavns Universitet. Essayet omfatter selvfølgelig ikke alt forskning med relation til islam, men er et produkt af undertegnedes syns- og interessefelt. Udgangspunktet er derfor universitets store islamsatsning, hvis virke og ambition skitseres, men også en håndfuld andre vigtige forskningsprojekter og 
-dagsordener trækkes frem, da de er med til at tegne den eksisterende islamforskning og giver et indblik $\mathrm{i}$, hvor islamforskningen på KU bevæger sig hen.

\section{Islamsatsningen på Københavns Universitet, 2008-2013}

Det var tydeligt både i lyset af den internationale krise, som muhammedtegningerne ansporede, og fra de politiske og samfundsmæssige debatter, at islam havde en fortsat voksende rolle i de nationale og internationale spørgsmål. På Københavns Universitet kom dette til udtryk som en stor efterspørgsel efter aktuel islamforskning, og det blev besluttet, at denne skulle opprioriteres. Da Grundforskningsfonden i 2007 efter ansøgning fra Det Teologiske Fakultet valgte at udnævne Jørgen S. Nielsen, der på daværende tidspunkt var direktør for Det Danske Institut i Damaskus, som såkaldt DG professor med en bevilling på 19,7 mio. kr., fulgte Københavns Universitet op og spejlede bevillingen, så der på TORS med Jakob SkovgaardPetersen i spidsen kunne satses tværfakultært på islamforskningen. Det blev til en dobbeltcenterstruktur med Jørgen S. Nielsen som leder af Center for Europæisk Islamisk Tænkning (CEIT) på Det Teologiske Fakultet og med Jakob SkovgaardPetersen som professor (mso) og leder af Center for den Nye Islamiske Offentlighed (CNIO). Førstnævnte havde til opgave at afsøge og forstå islamisk religiøs tænkning i både islams og Europas kontekst, hvorimod forskningsgruppen i CNIO arbejdede med muslimers anvendelse af medier og islams nye offentlige fremtræden.

1. Om centeret, dets medarbejdere og forskning: teol.ku.dk/ceit/english/ (besøgt 3. oktober 2016).

\section{Center for Europæisk Islamisk Tænkning'}

Jørgen S. Nielsen satte sit hold af forskere med tværfaglige kompetencer, og han havde blik for, at islamforskningen ikke som udgangspunkt var noget, der naturligt boede på Det Teologiske Fakultet. Safet Bektovic, der havde skrevet ph.d. på teologi om Søren Kierkegaards filosofi i forhold til islam, blev forskningslektor og udgav i 2012 bogen Islamisk filosofi. Baggrund, problemstillinger og moderne udformninger. Thomas Hoffmann, der 
2. Rapporten Danish Regulation of Religion, State of Affairs and Qualitative Reflections er frit tilgængelig og kan hentes på Københavns Universitets hjemmeside. Den er til dato blevet hentet mere end 11.ooo gange. teol.ku.dk/ ceit/religare/Danish_Report_Final_2012.pdf (besøgt 3. oktober 2016). kom fra en stilling som postdoc på TORS, blev ansat som forskningsadjunkt, inden han i 2009 tog til Århus - for en stund. Riem Spielhaus fra Humboldt Universitetet i Berlin blev postdoc i 2009, og gennem resten af centerets tid forskede hun i dannelsen af muslimske trossamfund, især i Tyskland, men med relation til resten af Europa. Centeret havde ligeledes gavn af forskning ved Birgitte Schepelern Johansen som postdoc og Lissi Rasmussen og Gina Smith som tilknyttede forskere. To ph.d.er blev tilknyttet centeret med komplementære forskningsinteresser mellem det ikke-organiserede og det organiserede hos muslimer i Europa: Nadia Jul Jeldtoft med en afhandling om Everyday Lived Islam fra 2012 og Niels Valdemar Vinding med afhandlingen Muslim Positions in the Religio-Organisational Fields of Denmark, Germany and England fra 2013.

En vigtig del af centerets arbejde var central deltagelse i RELIGARE, et treårigt forskningsprojekt om religiøs pluralisme og sekularisme i Europa, finansieret af Europa-Kommissionens 7th Framework Programme og med deltagelse fra 12 forskellige europæiske forskningsinstitutioner. Det danske bidrag var især Niels Valdemar Vinding og Lisbet Christoffersens rapport Danish Regulation of Religion, State of Affairs and Qualitative Reflections fra 2012, ${ }^{2}$ der med 18 eliteinterview på tværs af fire temaer gav indblik i danske forhold til internationale kolleger og aftagere. Et andet af centerets blivende bidrag er Jørgen S. Nielsens meget store produktion som redaktør gennem forlaget Brill, hvilket blandt andet tæller 22 udgivelser i Muslim Minorities-serien, Yearbook on Muslims in Europe, som nu med sin ottende årlige udgave giver overblik over muslimer i hele det udvidede Europa, samt Journal of Muslims in Europe, der på sjette år udgiver peer-reviewede artikler om aktuelle emner om islam og muslimer i Europa fra alle discipliner og på tværs af hele regionen.

Som en slags efterord til centerets arbejde blev Thomas Hoffmann i 2013 kaldet til Det Teologiske Fakultet som professor (mso) i koran- og islamstudier på Afdeling for Bibelsk Eksegese for at arbejde med koranstudierne i en bredere islamvidenskabelig kontekst. Niels Valdemar Vinding kom som adjunkt til TORS i 2014 med en treårig Carlsbergbevilling til forskningsprojektet "Imamer i Vesten". 


\section{Center for den Nye Islamiske Offentlighed}

Center for den Nye Islamiske Offentlighed blev oprettet i 2008 med en femårig finansiering fra Københavns Universitet med Jakob Skovgaard-Petersen som centerleder. Hans forskningsfelt er moderne islam i den arabiske verden, særligt de transformationer, muslimers erfaringer og opfattelser af deres religion har gennemløbet med tilblivelsen af moderne stater og offentligheder. Han har særligt samlet sig om gruppen af de islamiske lærde, al-ulama, og skrevet om deres læreinstitutioner, metoder, forhold til staten og internationale organisationer. Meget i forlængelse af dette arbejde var det centerets opgave at kortlægge og analysere, hvordan nye mellemøstlige medier, såsom satellitTV og internet, i de år var i færd med at ændre islamiske normer, politik og identitet. De transnationale medier har siden 1990'erne skabt en række nye offentlighedsformer, der gør det muligt for muslimer at kommunikere og interagere med trosfæller på tværs af stater og regioner, og som samtidig har svækket de enkelte staters mulighed for at kontrollere kultur og religion i deres medier. Fremkomsten af nye medier er faldet sammen med en større islamisk vækkelse siden 1980’erne, og de to udviklinger udgør tilsammen en udfordring for de sekulære moderne offentligheder, der har domineret de fleste mellemøstlige samfund siden anden verdenskrig.

Ved centerets oprettelse blev følgende ansatte tilknyttet: adjunkt Sune Haugbølle, adjunkt Ehab Galal og adjunkt Daniella Kuzmanovic. Efterfølgende blev også adjunkt Rasmus Christian Elling tilknyttet. Desuden har to ph.d.-studerende været tilknyttet centret: Donatella Della Ratta, der i 2013 forsvarede afhandlingen Dramas of the Authoritarian State: The Politics of Syrian $T V$ Serials in the Pan Arab Market, og Rikke Hostrup Haugbølle, der i 2014 forsvarede afhandlingen Reformer under autoritore regimer. En etnografisk tilgang. Samfundsmossige og individuelle reaktioner på reformer $i$ Tunesien, 1956-2011. Ehab Galal, der i 2009 forsvarede sin afhandling Identiteter og Livsstil på islamisk Satellit-TV: En indholdsanalyse af udvalgte programmers positionering af Muslimer har været på TORS siden CNIO og er nu lektor og forsker i islamistiske partiers mediestrategier i Egypten med det formål at studere politiske og kulturelle forandringsprocesser efter det arabiske forår. Han er ligeledes program 
manager for det Det Arabiske Initiativs Fund for Academic Cooperation and Exchange (FACE).

\section{Forskning i moderne og global islam}

Københavns Universitet er selvsagt kendetegnet ved højt kvalificeret islamforskning både før, ved siden af og i særdeleshed efter islamsatsningen. I midten af 1980'erne finansierede Statens Humanistiske Forskningsråd initiativet Islam i Nutiden, og en række forskningsprojekter om islam og muslimer i Danmark blev finansieret på den måde. Jørgen Bæk Simonsen gennemførte således en kortlægning af islams institutionelle etablering i Danmark med afhandlingen Islam i Danmark: Muslimske Institutioner i Danmark 1970-1989, der udkom i 1990. Med sin ansættelse ved Carsten Niebuhr Instituttet fortsatte han dette arbejde og publicerede gennem 1990'erne og oo'erne en lang række artikler i danske og udenlandske tidsskrifter - suppleret med Det retfoerdige samfund. Om islam, muslimer og etik i 2001, Islam med danske øjne. Danskernes syn på islam gennem 1000 år $\mathrm{i}$ 2004, Hvad er islam? i 2006 og Politikens bog om islam i 2008. Han har de seneste år brugt sin forskningstid til at gennemgå Johannes Pedersens efterladte papirer med henblik på en videnskabshistorisk biografi om hans betydning for studiet af islam. ${ }^{3}$

Fra 2006 til 2011 var han leder af Forskerskole for Regionale Studier finansieret af en bevilling fra Statens Humanistiske Forskningsråd og med formel tilknytning til Tværkulturelle og Regionale Studier og fungerede fra 2005 og frem til 2013 som professor (mso). Et af de ph.d-projekter, der blev finansieret efter ansøgning fra forskerskolen, er den ambitiøse og vigtige forskning, som Saer El-Jaichi under vejledning af Joshua A. Sabih afsluttede i 2016 med afhandlingen Early philosophical Sufism: The neoplatonic thought of Ibn M. al-Hallag.

I det seneste tiår har lektor, dr. theol., Joshua A. Sabih været central i den klassiske og kritiske islamforskning på universitetet. Han har især arbejdet med muslimske og jødiske relationer, som disse kommer til udtryk i både klassiske og samtidige politiske, filosofiske og religiøse diskurser. Resultaterne af denne

3. Se Jørgen Bæk Simonsens artikel om Johannes Pedersen $\mathrm{i}$ indeværende nummer. forskning blev til den teologiske doktordisputats Japheth ben Alis Book of Jeremiah: A Critical Edition and Linguistic Analysis of the Judaeo-Arabic Translation, som blev udgivet på Equinox 
Publishing i 2009. Endvidere har Joshua A. Sabih sammen med Saer El-Jaichi udgivet oversættelsen af Averroës' berømte fatwa Den afgørende diskurs (Fasl al-Maqāl) om filosofiens og den kritiske fornufts forhold til og forudsætning for tro, I Averröes' fodspor: samtalen mellem religion og filosofi fra forlaget Gamma 2013. Det er en vigtig og pædagogisk tekst i oversættelse og med kommentarer, som de studerende i undervisningen har taget godt imod.

Nye og gamle kræfter på tværs af TORS bidrager med forskning og undervisning i islam. Professor i religionshistorie Catharina Raudvere bidrager med sit Carlsbergprojekt The Many Roads in Modernity - The Transformation of South-East Europe and the Ottoman Heritage from 1870 to the Twenty-first Century (2012-2016) til bredden i islamforskningen. Med fokus på Sydøsteuropa og Tyrkiet og påvirkningen fra det sen-osmanniske rige forfølger projektet mange af de modernitetsprocesser og udviklinger, som kendetegner det 2o. århundrede og årene frem til i dag. Her er krig og konflikt, tradition, generation, identitetsog nationalitetsdannelse og mange relaterede temaer i fokus og ses fra bl.a. muslimsk og de muslimske befolkningers synspunkt.

Lektor Brian Arly Jacobsen har i årevis skrevet om islam og muslimer i Danmark og om, hvordan de organiserer sig, institutionaliserer sig og forholder sig til den stigende politisering af religion i Danmark. Særlig denne politisering og italesættelse af religion er i fokus i hans afhandling fra 2009, Religion som fremmedhed $i$ dansk politik: En sammenligning af italesœttelser afjøder i Rigsdagstidende 1903-45 og muslimer i Folketingstidende 1967-2005. I sit nuværende projekt undersøger Brian Arly Jacobsen religion og lokalpolitik i Danmark med fokus på, hvordan religionsmodeller på et lokalt niveau spiller sammen med sekularisering, politisering og medier. Her er studiet af moskeer og moskébyggeri et tilbagevendende eksempel, hvor han bringer mange religionssociologiske perspektiver i spil i forhold til islamforskningen.

Per 1. januar 2015 er Simon Stjernholm blevet ansat som lektor i religionshistorie på TORS. Han forsker i samtidig sufisme, muslimske prædikanter, religiøs autoritet og religion i offentligheden i både Danmark og Sverige. Forskningsadjunkt Rubya Mehdi har været tilknyttet TORS i en længere årrække og har arbejdet og undervist islamiske studier og moderne indienstudier. Hun har som jurist arbejdet med kvindelige dommere i Pa- 
kistan og i resten af den muslimske verden, og hun har arbejdet med muslimske kvinder, der er kommet i klemme i familie- og privatretlige problemstillinger. Hun er forfatter til Integration \& retsudvikling (Religion i det 21. århundrede, nr. 14) fra 2007 om traditionel, islamisk familieret og en række relaterede spørgsmål, såsom for eksempel ægteskabskontrakt, morgengave, børn, økonomiske forhold i ægteskabet og skilsmisse i forhold til dansk ret.

Lektor Alessandro Gori leder det store internationale forskningsprojekt IslHornAfr: Islam in the Horn of Africa, A Comparative Literary Approach, med støtte fra det europæiske 7 th Framework Programme og fra European Research Council fra 2013 til 2018. Projektet er et vigtigt bidrag til både Afrika- og islamforskning og undersøger den islamiske kultur- og litteratur-historie i Etiopien, Eritrea, Djibouti og Somalien. På tværs af arabisk, somali og mange af de andre lokale sprog samler Alessandro Goris hold manuskripter og tekster, som skal kaste nyt lys over kilderne til forbindelserne mellem Afrikas Horn og resten af den islamiske verden.

Lektor Ildikó Bellér-Hanns forsker i kinesiske muslimer og i uighurerne i Xinjiang i det nordøstlige Kina. Ildikó BellérHann følger det etniske og religiøse uighur-mindretals kamp for at beholde identitet og særtræk i det dobbelte møde mellem en voldsom kinesisk centralmagt på den ene side og islamiserende globale kræfter på den anden. De muslimske uighurer er marginaliserede i et kinesisk kulturprojekt, og internationale islamistiske tendenser tilbyder sig som en ressource, men dette udstilles i den kinesiske politiske kontekst som sympati for terrorisme og fremmede magter.

Lektor Claus Valling Pedersen forsker i persisk, iranske forhold og de komplekse magtforhold, der udspiller sig her, hvilket bl.a. inkluderer tolver-shiismen. Få steder har de islamistiske kræfter fået magten som i Iran, hvor Ayatollah Khomeini i 1979 gennemførte den islamiske revolution. På mange måder ligger Iran både i og uden for Mellemøsten samtidig med at det er bindeled mellem Europa og Sydøstasien. Claus Valling Pedersens forskning ser på Irans historie, ideer, religion og politik. der har så stor international bevågenhed i disse år. I et temanummer af Religionslærerforeningens tidsskrift Religion (nr. 4., december 2015) er samlet bidrag fra Alessandro Gori, Ildikó BellérHann, Claus Valling Pedersen og Niels Valdemar Vinding, der 
fint illustrerer, hvordan TORS har samlet de tværfaglige kompetencer om islam i den globale verden på tværs af instituttet.

I tillæg til det allerede nævnte, er der de sidste ti år udgivet en række ph.d.-afhandlinger inden for islam og relaterede forskningsemner. Dorthe Bramsen forsvarede i 2007 sin ph.d.afhandling i islamiske studier Divine Law and Human Understanding: Interpreting Sharîa within the Institution of Iftâ and Qadâ in Saudi Arabia. Jean Butler forsvarede sin afhandling Myth and Memory - Satan and the Other in Islamic Tradition i 2008 og arbejder nu med sin viden om militant islamisme, terrorisme og islamisk ideologi i sin job som analytiker i forsvaret. Marie Juul Petersens afhandling For Humanity or for the Umma? Ideologies of Aid in four transnational Muslim NGOs blev forsvaret i 2011, og hun er nu postdoc på Institut for Menneskerettigheder, hvor hun arbejder med menneskerettigheder og religion, islamistiske og muslimske organisationer, religionsfrihed, udvikling og humanitær hjælp.

På tværs af Københavns Universitets øvrige fakulteter, er der gode eksempler på fremragende islamforskning. På institut for antropologi har lektor og studieleder Heiko Henkel forsket i de sociale sammenhænge, der betinger den måde den islamiske tradition fortolkes af muslimer såvel som ikke-muslimer. Han har også skrevet om det komplekse politiske spil forbindelse med Muhammedkrisen og islamismens trusler i Danmark. På det juridiske fakultet har professor i forfatningsret Antoni Abat Ninet siden 2013 været tilknyttet Centre for European and Comparative Legal Studies. Hans forskning i forfatningsret går på tværs af retstraditioner og retskulturer, hvilket kommer til udtryk i hans nuværende forskning i messianisme og forfatningsret, som er højaktuelt for studier af det arabiske forår og islamisk stat.

\section{Fortsat fokus også på formidling}

Det seneste tiår er rig på eksempler på formidling af forskning i islamiske studier på Københavns Universitet, der når langt ud til den brede offentlighed, men som i særdeleshed rammer ind i mange af samtidens store politiske debatter og kontroverser. Som supplement til, hvad der ellers er fremhævet om formidling i form af publikationer, skal her fremhæves to eksempler på for- 
midling til offentligheden og til debatten om islam og islamrelaterede emner.

\section{Carsten Niebuhr Biblioteket ${ }^{4}$}

Carsten Niebuhr Biblioteket er en bogserie om islamisk kunst, kultur, samfundsforhold og religion forfattet af internationale islamforskere og oversat til dansk. Carsten Niebuhr Biblioteket, som nåede op på 28 bøger, udkom 2003-2016 i et samarbejde mellem C.L. Davids Fond og Samling, Carsten Niebuhr Afdelingen på Københavns Universitet og Forlaget Vandkunsten. Serien blev redigeret af professor Jakob Skovgaard-Petersen, redaktør Pernille Bramming og arkitekt og professor emeritus Hans Munk Hansen. En af de sidste udgivelser i serien var Guds Styre om islamisk politisk tænkning igennem seks århundreder, skrevet i 2004 af nyligt afdøde Patricia Crone.

Udgiverne præsenterede serien og baggrunden for Carsten Niebuhr Biblioteket med henvisning netop til den til tider heftige debat om islamisk kultur og religion, som pågår i de danske medier. Serien var imidlertid ikke tænkt som et debatindlæg, men derimod som et forsøg på at sikre, at der fortsat fandtes en videnskabeligt lødig litteratur om islam på dansk, så offentligheden kunne få et bredere og mere sagligt indblik i islamisk kunst, kultur og religion. Mange, endda hovedparten, af bøgerne drejer sig om emner, som ikke har direkte forbindelse til den nutidige debat om islam. For serien, som for islamforskningen generelt, er muslimer til alle tider og steder principielt af interesse, og det ses som fortjenstfuldt at oplyse om noget, som seriens læsere ikke kender meget til i forvejen. Til hver af bøgerne hører et præsentationsblad, som stadig kan læses på Bibliotekets hjemmeside.

4. Dele af dette afsnit er gengivet fra bogseriens hjemmeside: forlagetvandkunsten.dk/97496/ (besøgt 3 . oktober 2016).

5. Rapporten ligger frit tilgængelig på Københavns Universitets hjemmeside: e-pages.dk/ku/322/ (besøgt 3. oktober 2016).

\section{Burka-rapporten 5}

Et glimrende eksempel på styrken i islamforskningens tværfaglige bredde på TORS kan hentes fra den såkaldte Rapport om brugen af niqab og burka fra 2009, som blev rekvireret af den daværende regerings arbejdsgruppe om burka og anden lignende beklædning under Indenrigs- og Socialministeriet. Styrken i rapporten er, at den falder i to komplementære dele. Første del er en religionssociologisk kortlægning af anvendelsen af an- 
sigtsdækkende beklædningsgenstande, først og fremmest i Danmark. Den er udarbejdet af Birgitte Schepelern Johansen og Kate Østergaard under ledelse af Margit Warburg. Anden del handler om den religionshistoriske baggrund for anvendelse af ansigtsdækkende beklædningsgenstande og er udført af cand. mag. Anne Nybo, Iram Nisa Asif, Claus Valling Pedersen, Daniella Kuzmanovic, Lars Døssing Rosenmeier og Rikke Hostrup Haugbølle under ledelse af Jakob Skovgaard-Petersen i regi af CNIO. På den måde giver rapporten en klar sociologisk kortlægning af udbredelsen af niqab og burka i Danmark med stærke paralleller til de lande, Danmark normalt sammenligner sig med, hvorefter rapporten sætter emnet $i$ international og historisk kontekst.

Rapporten var et første forsøg i en dansk kontekst på, på systematisk vis, at samle viden om kvinder, der bærer beklædning, der dækker ansigtet. Rapportens forfattere vurderer på baggrund af de tilgængelige tal, deloptællinger og viden fra sammenlignelige lande, at der i Danmark findes mellem 100 og 200, der bærer niqab eller burka. I lyset af de løbende diskussioner om kvindesynet $\mathrm{i}$ islam, om integration og om radikalisering er det for læseren af rapporten svært at fastholde, at tildækning af ansigtet er et udbredt problem i Danmark.

\section{Udfordrende og udfordret undervisning: islamiske studier som kandidatuddannelse}

Fra 2004 er det blevet muligt på Københavns Universitet at læse en kandidat $\mathrm{i}$ islamiske studier. Her får man som studerende en grundig indføring i en række emner inden for islamisk teologi, jura, mystik, historie, sociologi, politik, filosofi og kritisk tænkning i såvel muslimske majoritets- som minoritetssamfund med hovedvægt lagt på det 20. og 21. århundrede. Et vigtigt fokus i undervisningen har i mange år været moderne arabisk-islamisk filosofi og religionskritik samt orientalisme og orientalismekritik. Målet med kandidatuddannelsen i islamiske studier er at uddanne humanistiske kandidater, der har en professionel og videnskabeligt baseret kompetence $\mathrm{i}$ islamiske forhold på et højt niveau og er rustede til at varetage professionsudøvelse inden for en række fagområder (integrationsområdet, journalistik, forskning, undervisning) i statslige og private virksomheder 
såvel som nationale og internationale ngoer, der arbejder i den globale, islamiske verden. Det er bemærkelsesværdigt ved kandidatuddannelsen i islamiske studier, at den til trods for sin relativt korte levetid og sit meget beskedne optag alligevel har kastet fem ph.d.-studerende af sig, fordelt på København, Roskilde, Aarhus og Lund.

I juni 2015 blev kandidatuddannelsen i islamiske studier genakkrediteret efter en længere sagsbehandling og grundigt gennemsyn af uddannelsen, bl.a. ved professor Seyed Mohammad Fazlhashemi, Uppsala Universitet, og professor Knut Vikør fra Bergen Universitet. Uddannelsen blev vurderet tilfredsstillende på samtlige kriterier og dermed sikret de næste mange år. Allerede inden tilbagemeldingen om den positive akkreditering blev uddannelsen "dimensioneret" og dermed hårdt skåret til på et meget lavt optag, som i praksis ikke er bæredygtigt for en uddannelse i sin egen ret. Det er med andre ord en glimrende, men stærkt udfordret uddannelse, og der er et udpræget behov for at nytænke og genprioritere islamiske studier på Københavns Universitet.

Der er heldigvis mange stærke ressourcer at trække på fra hele Københavns Universitet. På TORS og på tværs af universitetet udbydes i samarbejde med universiteter i IARU med jævne mellemrum en international master class med temaet Islam og Muslimer i den Moderne Verden, hvor studerende fra flere lande og gæstelærere fra udlandet deltager. Her er fokus på islam og muslimer i sine globale og samtidige sammenhænge. Hvordan ser den moderne muslimske verden ud? Hvordan tænker man islam både globalt og lokalt? Hvilke ligheder findes der blandt muslimer til trods for de meget store forskelle i praksis og levevis? Med disse spørgsmål i et genfokuseret uddannelsesudbud tilbyder Københavns Universitet et meget bredere udblik, end islamforskningen traditionelt giver, men håber også at give et nyt stærkt fokus på det, som forener og udfordrer islam og muslimer fra Kina til Danmark.

På Det Humanistiske Fakultet eksisterer også en faglig forening, der bl.a. henvender sig til studerende og kandidater fra islamiske studier, nemlig NASIM, der både betyder "brise" på arabisk, hebraisk og persisk og er forkortelsen af Netværket af Akademikere, Studerende og Interesserede i Mellemøsten. Foreningen afholder foredrag og andre arrangementer og har en hjemmeside på nettet og på Facebook. Mange af forskerne på 
fakultetet er også medlemmer af foreningen, og dermed opretholdes en uformel, men vigtig kontakt på tværs af fagligheder og institutter.

Fra sommeren 2015 har man på Det Teologiske Fakultet kunnet tage kurser i islamisk teologi og praksisformer. Organiseret som en række valgfag fokuseres der på islams teologiske hovedkilder: Koranen, hadith og centrale tekster fra traditionen i relation til de vigtigste islamiske tolkningstraditioner. Fokus er samtidig på centrale islamiske praksisformer i de vestlige samfund i dag. Hovedvægten ligger således på islams helligskrifter og deres forhold til de islamiske praksisformer, forkyndelse, ritualer, spiritualitet, åndelig omsorg og social etik. Islam studeres både udefra og indefra: Islamisk teologi og praksis undersøges på baggrund af den historiske kontekst, den er udviklet i, men samtidig studeres den eller de aktuelle tolkninger og udfoldelser af islam, som findes blandt muslimer i Europa i dag.

\section{Korte afsluttende bemærkninger}

Det gælder for både islamforskningen og kandidatuddannelsen islamiske studier på Københavns Universitet, at de hverken nominelt eller organisatorisk er højt prioriteret. Fyringsrunder, dimensionering og manglende fokus over længere tid har gjort, at islamforskning og islamiske studier står diffust og uden klar retning. Set i tidens lys er islamforskning et vigtigt fagfelt, og der er uden tvivl en højt kvalificeret og bredt funderet gruppe af forskere og undervisere på tværs af fagskel, discipliner, institutter og fakulteter. Der er mange lovende større og mindre forskningsprojekter, der fortsat kaster resultater af sig. Ligeledes er der igennem det seneste tiår blevet uddannet dygtige kandidater og forskere, som har fundet plads både inden for og uden for universitetet. Det bør derfor ikke blot være et håb, men også en klar ambition for alle, der bidrager til islamforskningen på universitetet, at finde faglig samling og fælles kritik på tværs af forskningsinteresser og discipliner. Der er med Jørgen S. Nielsens formulering kritisk masse af kvalificeret islamforskning, og ud af den kan der - ikke kun forankret i København, men på tværs af Danmark - vokse et miljø for islamforskning af international kaliber. I det seneste tiår er grundstenene helt sikkert 
lagt til noget sådan, og det burde være muligt at realisere inden for de næste ti år.

\section{Litteratur}

Bektovic, Safet. 2012. Islamisk filosofi. Baggrund, problemstillinger og moderne udformninger. København: Forlaget Anis.

Bellér-Hann, Ildikó. 2015. "Islam og Muslimer i Kina.” Religion 4: 10-20.

Buhl, Frants. 1924. Muhammeds religiøse Forkyndelse efter Quranen. København: Schultz Forlag.

- 1921. Ali som Protendent og Kalif. København: Københavns Universitet.

- 1903. Muhammeds Liv. Med en Indledning om Forholdene $i$ Arabien for Muhammeds Optrceden. København: Gyldendalske Boghandels Forlag. Butler, Jean. 2008. Myth and Memory - Satan and the Other in Islamic Tradition. Ph.d.-afhandling. København: Det Humanistiske Fakultet.

Crone, Patricia. 2016. Guds Styre. København: Forlaget Vandkunsten.

Della Ratta, Donatella. 2013. Dramas of the Authoritarian State: The Politics of Syrian TV Serials in the Pan Arab Market. Ph.d.-afhandling. København: Det humanistiske Fakultet.

El-Jaichi, Saer. 2016. Early philosophical Sufism: The neoplatonic thought of Ibn M. alHallag. Ph.d.-afhandling. København: Det humanistiske Fakultet.

Galal, Ehab. 2009. Identiteter og Livsstil på islamisk Satellit-TV: En indholdsanalyse af udvalgte programmers positionering af Muslimer. Ph.d.-afhandling. København: Det Humanistiske Fakultet.
Gori, Alessandro. 2015. "Bag om konflikternes paradigme: Muslimer og kristne i Etiopien og Eritrea." Religion 4: 38-50.

Haugbølle, Rikke Hostrup. 2014. Reformer under autoritore regimer. En etnografisk tilgang. Samfundsmoessige og individuelle reaktioner på reformer $i$ Tunesien, 1956-2011. Ph.d.-afhandling. København: Det humanistiske Fakultet.

Jacobsen, Brian Arly. 2009. Religion som fremmedhed $i$ dansk politik: En sammenligning af italesattelser af jøder i Rigsdagstidende 1903-45 og muslimer $i$ Folketingstidende 1967-2005. Ph.d.-afhandling. København: Det Humanistiske Fakultet.

Jeldtoft, Nadia Jul. 2012. Everyday Lived Islam. Ph.d.-afhandling. København: Det Teologiske Fakultet.

Løkkegaard, Frede. 1972. Muhammad. København: G. E. C. Gads Forlag. - 1950. Islamic Taxation in the Classical Period, with Special Reference to Circumstances in Iraq. København: Branner und Korch.

Mehdi, Rubya. Integration \& retsudvikling. Religion i det 21. århundrede, nr. 14. København: Jurist- og Økonomforbundets Forlag.

Pedersen, Claus Valling. 2015. "Shi'a-islam og det politiske system i Iran." Religion 4: 32-37. Pedersen, Johannes. 1960. Kitab Tabaqat al-Sufiyya. Texte arabe avec une introduction et un index par Johannes Pedersen. Leiden: Brill. 
- 1923. Muhammedansk Mystik. En Samling Texter oversat og forklaret af Johs. Pedersen. Tuxen, Poul \&

Marcus, Aage (red.). København: Gyldendal.

Simonsen, Jørgen Bæk. Politikens bog om islam. København: Politikens Forlag, 2008.

- 2006. Hvad er islam? København: Akademisk Forlag.

- 2004. Islam med danske øjne. Danskernes syn på islam gennem 1000 år. København: Akademisk Forlag.

- 2001. Det retfordige samfund.

Om islam, muslimer og etik.

København: Forlaget Samleren.

- 1990. Islam i Danmark:

Muslimske Institutioner $i$

Danmark 1970-1989. Aarhus:

Aarhus Universitetsforlag.

- 1988. Studies in the Genesis and

Early Development of the Caliphal Taxation System. København:

Akademisk Forlag.
Petersen, Marie Juul. 2011. For Humanity or for the Umma? Ideologies of Aid in four transnational Muslim NGOs. Ph.d.afhandling. København: Det Humanistiske Fakultet.

Sabih, Joshua A. 2009. Japheth ben Alis Book of Jeremiah: A Critical Edition and Linguistic Analysis of the Judaeo-Arabic Translation. London: Equinox Publishing. Sabih, Joshua A., og Saer El-Jaichi. 2013. I Averröes' fodspor: samtalen mellem religion og filosofi.

København: Forlaget Gamma.

Skovgaard-Petersen, Jakob. 1997.

Defining Islam for the Egyptian State: Muftis and Fatwas of the Dâr al-Iftâ. Leiden: Brill Publishers.

Vinding, Niels Valdemar. 2015. "Sharīa i Europa." Religion 4: 5261.
- 2013. Muslim Positions in the Religio-Organisational Fields of Denmark, Germany and England. Ph.d.-afhandling. København: Det Teologiske Fakultet.

Vinding, Niels Valdemar, og Lisbet Christoffersen. 2012. Danish Regulation of Religion, State of Affairs and Qualitative Reflections. København: Det Teologiske Fakultet.

Warburg, Margit, et al. 2009. Rapport om brugen af niqab og burka. København: Københavns Universitet.

Østrup, Johannes. 1914. Islam. Den muhammedanske Religion og dens historiske Udvikling i kortfattet Fremstilling. København: G.E.C. Gad.

- 1911. Profeten Muhammad. En folkelig Fremstilling. København: Kunstforlaget Danmark. 